\title{
A diVlsive Shuffling Approach (VIStA) for gene expression analysis to identify subtypes in Chronic Obstructive Pulmonary Disease
}

\author{
Jörg Menche ${ }^{1,2,3 \dagger}$, Amitabh Sharma ${ }^{1,2 \dagger}$, Michael H Cho ${ }^{4}$, Ruth J Mayer ${ }^{5}$, Stephen I Rennard ${ }^{6}$, Bartolome Celli, \\ Bruce E Miller ${ }^{5}$, Nick Locantore ${ }^{8}$, Ruth Tal-Singer ${ }^{5}$, Soumitra Ghosh ${ }^{5}$, Chris Larminie ${ }^{9}$, Glyn Bradley ${ }^{9}$, John H Riley ${ }^{9}$, \\ Alvar Agusti $^{10,13}$, Edwin K Silverman ${ }^{4}$, Albert-László Barabási ${ }^{1,2,3,11,12^{*}}$
}

From High-Throughput Omics and Data Integration Workshop

Barcelona, Spain. 13-15 February 2013

\begin{abstract}
Background: An important step toward understanding the biological mechanisms underlying a complex disease is a refined understanding of its clinical heterogeneity. Relating clinical and molecular differences may allow us to define more specific subtypes of patients that respond differently to therapeutic interventions.

Results: We developed a novel unbiased method called diVlsive Shuffling Approach (VIStA) that identifies subgroups of patients by maximizing the difference in their gene expression patterns. We tested our algorithm on 140 subjects with Chronic Obstructive Pulmonary Disease (COPD) and found four distinct, biologically and clinically meaningful combinations of clinical characteristics that are associated with large gene expression differences. The dominant characteristic in these combinations was the severity of airflow limitation. Other frequently identified measures included emphysema, fibrinogen levels, phlegm, BMI and age. A pathway analysis of the differentially expressed genes in the identified subtypes suggests that VIStA is capable of capturing specific molecular signatures within in each group.
\end{abstract}

Conclusions: The introduced methodology allowed us to identify combinations of clinical characteristics that correspond to clear gene expression differences. The resulting subtypes for COPD contribute to a better understanding of its heterogeneity.

\section{Background}

Chronic obstructive pulmonary disease (COPD) is one of the most prevalent chronic diseases (4th cause of death globally), with increasing incidence worldwide. Understanding of the disease pathobiology is far from complete and only few novel therapeutic mechanisms of action have been identified. Tobacco smoking is the main risk factor for COPD, but only a fraction of all smokers develops the disease [1]. This variable response to smoking, plus the observation that COPD aggregates in families, strongly

\footnotetext{
* Correspondence: barabasi@gmail.com

+ Contributed equally

${ }^{1}$ Center for Complex Networks Research and Department of Physics,

Northeastern University, Boston, MA, 02115, USA

Full list of author information is available at the end of the article
}

suggest a genetic component to the disease [2-6]. Yet, COPD is a very heterogeneous and complex disease, with varied pulmonary and extra-pulmonary clinical manifestations [7]. Understanding and characterizing this biological and clinical heterogeneity could help identify subgroups of patients (subtypes) that may benefit from different therapeutic strategies [8]. To investigate the genomic and pathobiological basis of COPD subtypes with distinct clinical manifestations, we applied several novel and complementary computational strategies to differential gene expression analysis. We used expression data from induced sputum samples of former smokers with COPD and varying degree of airflow limitation. The patients are a subset of the large ECLIPSE cohort, which is a multicenter, 3 year observational international study that 
collected clinical, genetic, proteomic and biomarker measures in a population of COPD patients [9]. Specifically, in the current study we sought to: $(i)$ compare the gene expression pattern between patient groups with different clinical characteristics; ( $i$ i) conversely, assess the clinical characteristics of groups of patients with distinct gene expression patterns identified by a novel diVIsive Shuffling Approach (VIStA) developed specifically for this purpose (see below). Unexpectedly, we found that the reverse approach (ii) showed greater potential to identify specific pathways that may offer novel therapeutic targets [10] than the traditional approach $(i)$.

\section{Methods}

Study design, participants and ethics

The ECLIPSE cohort is a large, prospective, observational and controlled study (Clinicaltrials.gov identifier NCT00292552; GSK study code SCO104960), whose design has been published previously [9]. Here, we investigated differential gene expression in induced sputum samples of a subset of the participants that included 140 former smokers with COPD (70 with moderate or GOLD stage 2 and 70 with severe or GOLD stage 3-4 airflow limitation, matched for age and gender) with characterized clinical and laboratory measures (Table 1). Sputum induction and processing with dithiothreitol (DTT) was performed using standard methods as described previously [5], details on the generation and processing of the expression data can be found in [3]. The ECLIPSE study complies with the Declaration of Helsinki and Good Clinical Practice Guidelines and was approved by the Ethics Committees and Institutional Review Boards of all participating centers. All participants provided written informed consent.

\section{Selection of clinical measures}

Table 2 shows the clinical measures selected by COPD experts (SR, BC, AA, EKS) based on their association to important clinical outcomes (e.g. exacerbations, hospitalizations and death). The degree of airflow limitation (GOLDCD) was determined using spirometry, distances walked over 6 minutes (DWALK) were measured using standard methodology. Standardized questionnaires were used to obtain smoking status, cough and sputum (PHLEGM) production. COPD exacerbations in the year prior to the study were recorded, as well as body mass index (BMI). All subjects underwent a low-dose computed tomography (CT) scan of the chest to determine both airway disease and emphysema (FV950 as a quantitative assessment, and EMPHETCD as a radiologists score) [11]. Several inflammatory biomarkers were measured in peripheral blood [12]. For details on the definitions and acquisition procedures of the above measures see [9].
Table 1 Summary of the characteristics of 140 subjects with sputum gene expression data from the ECLIPSE Cohort.

\begin{tabular}{ll}
\hline Demographics and clinical data & \\
\hline Age, yrs. & $65 \pm 5.5$ \\
Males, \% & 66 \\
Body mass index, Kg/m ${ }^{2}$ & $26.8 \pm 5.2$ \\
Smoking exposure, pack-yrs. & $48.3 \pm 29.1$ \\
Annual Exacerbation rate, year ${ }^{-1}$ & $0.98 \pm 1.6$ \\
\hline Lung function & \\
\hline FEV1, L & $1.26 \pm 0.45$ \\
FEV1, \% revers. & $9.5 \pm 10.4$ \\
FEV1/FVC, \% & $43.2 \pm 11.5$ \\
\hline Imaging & \\
\hline Emphysema, -950HU \% & $19.2 \pm 12.2$ \\
Emphysema, extent code & $2.8 \pm 1.8$ \\
\hline Systemic inflammation & \\
\hline hsCRP (mg/L) & $8.24 \pm 15.0$ \\
IL6 (pg/mL) & $7.8 \pm 36$ \\
IL8 (pg/mL) & $9.3 \pm 5.2$ \\
CCL18 (ng/mL) & $121.7 \pm 46$ \\
Fibronogen (mg/dL) - & $481.9 \pm 107.6$ \\
TNFA (ng/mL) & $103.2 \pm 624$ \\
SPD (ng/mL) & $120.6 \pm 78$ \\
\hline Induced sputum & \\
\hline Total cell count, $\times 10^{6}$ & $7.5 \pm 1.78$ \\
Neutrophils, \% & $64.8 \pm 8.5$ \\
Eosinophils, \% & $3.1 \pm 2.04$ \\
Lymphocytes, \% & $25.4 \pm 7.9$ \\
\hline Not & \\
\hline
\end{tabular}

Note that all subjects are COPD patients and former smokers. The values represent mean \pm standard deviation, frequency or proportion, as appropriate.

Note that there were no controls with normal lung function among the subjects. Hence, we cannot compare COPD to normal but only the differences between COPD patients [1].

\section{Relationship between clinical characteristics and gene expression}

To investigate the relationships between differences in gene expression and clinical trait occurrence, we used two complementary analyses:

(i) For each of the clinical characteristics introduced above, we divided the patients into two groups based on clinically relevant cut-points (Table 2, column 5 ) and computed gene expression differences between the two groups. Gene expression analysis was performed using Significance Analysis of Microarrays (SAM) [13] with a false discovery rate (FDR) of $5 \%$ as cutoff.

(ii) We used VIStA (see below) to identify groups of patients with maximized differential gene expression and then compared their clinical characteristics. 
Table 2 Summary of the clinical characteristics of COPD patients identified as most relevant by clinical experts.

\begin{tabular}{|c|c|c|c|c|c|}
\hline Category & $\begin{array}{c}\text { Continuous Variable for Quantitative } \\
\text { Analysis }\end{array}$ & Discrete Variable & Bins & Characteristics & $\begin{array}{c}\text { Differentially expressed genes } \\
\text { at FDR }<0.05\end{array}$ \\
\hline \multirow[t]{2}{*}{ Chronic Bronchitis } & Not applicable & $\begin{array}{c}\text { Cough with Phlegm for at least } 3 \text { mos/yr } \\
\text { for at least } 2 \text { years }\end{array}$ & $\begin{array}{l}\text { low extreme }(\mathrm{Q} 1 \\
\quad=64)\end{array}$ & $\begin{array}{l}\text { neither chronic cough nor } \\
\text { chronic phlegm }\end{array}$ & 0 \\
\hline & & & $\begin{array}{l}\text { high extreme } \\
(\mathrm{Q} 4=46)\end{array}$ & $\begin{array}{l}\text { both chronic cough and } \\
\text { chronic phlegm }\end{array}$ & \\
\hline \multirow[t]{2}{*}{$\begin{array}{l}\text { History of } \\
\text { Exacerbations }\end{array}$} & Number of exacerbations per year & $\begin{array}{c}2 \text { or more per year and less than } 2 \text { per } \\
\text { year }\end{array}$ & $\begin{array}{l}\text { low extreme (Q1 } \\
=26)\end{array}$ & 0 - Never & 0 \\
\hline & & & $\begin{array}{l}\text { high extreme } \\
(\mathrm{Q} 4=17)\end{array}$ & 3 - Always & \\
\hline \multirow[t]{2}{*}{$\begin{array}{l}\text { Body Mass Index } \\
\left(\mathrm{Kg} / \mathrm{m}^{2}\right)\end{array}$} & BMI & $\mathrm{BMI}<21,21-30,>30$ & $\begin{array}{l}\text { low extreme (Q1 } \\
=18)\end{array}$ & $\mathrm{BMI}<21$ & 0 \\
\hline & & & $\begin{array}{l}\text { high extreme } \\
(\mathrm{Q} 4=35)\end{array}$ & $\mathrm{BMI}>30$ & \\
\hline \multirow[t]{2}{*}{$\begin{array}{l}\text { Airflow Limitation } \\
\text { severity }\end{array}$} & FEV1 (\% predicted) & GOLD Stage & $\begin{array}{l}\text { low extreme }(\mathrm{Q} 1 \\
=69)\end{array}$ & $<2$-GOLD stage & 6,049 \\
\hline & & & $\begin{array}{l}\text { high extreme } \\
\qquad(\mathrm{Q} 4=13)\end{array}$ & $>4$ GOLD stage & \\
\hline \multirow[t]{2}{*}{$\begin{array}{l}6 \text { Minute Walk } \\
\text { Distance }\end{array}$} & Quantitative 6MWD & $<350$ meters and $>350$ meters & $\begin{array}{l}\text { low extreme (Q1 } \\
=38)\end{array}$ & $>350$ meters & 0 \\
\hline & & & $\begin{array}{l}\text { high extreme } \\
(\mathrm{Q} 4=101)\end{array}$ & $>350$ meters & \\
\hline $\begin{array}{l}\text { Radiologist } \\
\text { Emphysema }\end{array}$ & Emphysema severity category: & & $\begin{array}{l}\text { low extreme (Q1 } \\
=40)\end{array}$ & 0-1.5 -No emphysema & 0 \\
\hline \multirow[t]{6}{*}{ assessment } & Not affected (N): 0 & Yes/No/Uncertain & $\begin{array}{l}\text { high extreme } \\
(\mathrm{Q} 4=45)\end{array}$ & 4-5 - severe & \\
\hline & Trivial (T): 1 & & & & \\
\hline & Mild (M) 5-25\%: 2 & & & & \\
\hline & Moderate (O) 25-50\%: 3 & & & & \\
\hline & Severe (S) 50-75\%: 4 & & & & \\
\hline & Very Severe $(V)>75 \%: 5$ & & & & \\
\hline \multirow[t]{2}{*}{$\begin{array}{l}\text { Densitometric } \\
\text { Emphysema }\end{array}$} & Emphysema at $-950 \mathrm{HU}$ & Emphysema >10\% (Yes/No) & $\begin{array}{l}\text { low extreme }(\mathrm{Q} 1 \\
=37)\end{array}$ & Emphysema $>10 \%=\mathrm{No}$ & 0 \\
\hline & & & $\begin{array}{l}\text { high extreme } \\
\qquad(\mathrm{Q} 4=95)\end{array}$ & Emphysema $>10 \%=$ yes & \\
\hline \multirow[t]{2}{*}{ CT Airway Disease } & $\begin{array}{c}\text { Pi10 (Square root of wall area of } 10 \mathrm{~mm} \\
\text { internal perimeter airways) }\end{array}$ & $\begin{array}{c}\text { GOLD Stages 2-4 with Emphysema }<5 \% \\
\text { (Yes) or }>5 \%(\mathrm{No})\end{array}$ & $\begin{array}{l}\text { low extreme }(\mathrm{Q} 1 \\
\quad=63)\end{array}$ & Trivial $(<\% 5)$ & 0 \\
\hline & & & $\begin{array}{l}\text { high extreme } \\
(\mathrm{Q} 4=33)\end{array}$ & $\begin{array}{c}\text { Severe }(50-75 \% \text {, very severe } \\
(>75 \%))\end{array}$ & \\
\hline
\end{tabular}




\section{diVlsive Shuffling Approach (VIStA)}

We developed a novel unbiased method called diVIsive Shuffling Approach (VIStA) to identify groups of patients with maximal difference in gene expression. The algorithm consists of the following steps: (iii) $n$ subjects are randomly partitioned into three groups of comparable size (Figure 1A). A SAM analysis is performed and the number of genes differentially expressed between groups 1 and 2 is counted. Group 3 serves as a "reservoir" of individuals for the subsequent steps.
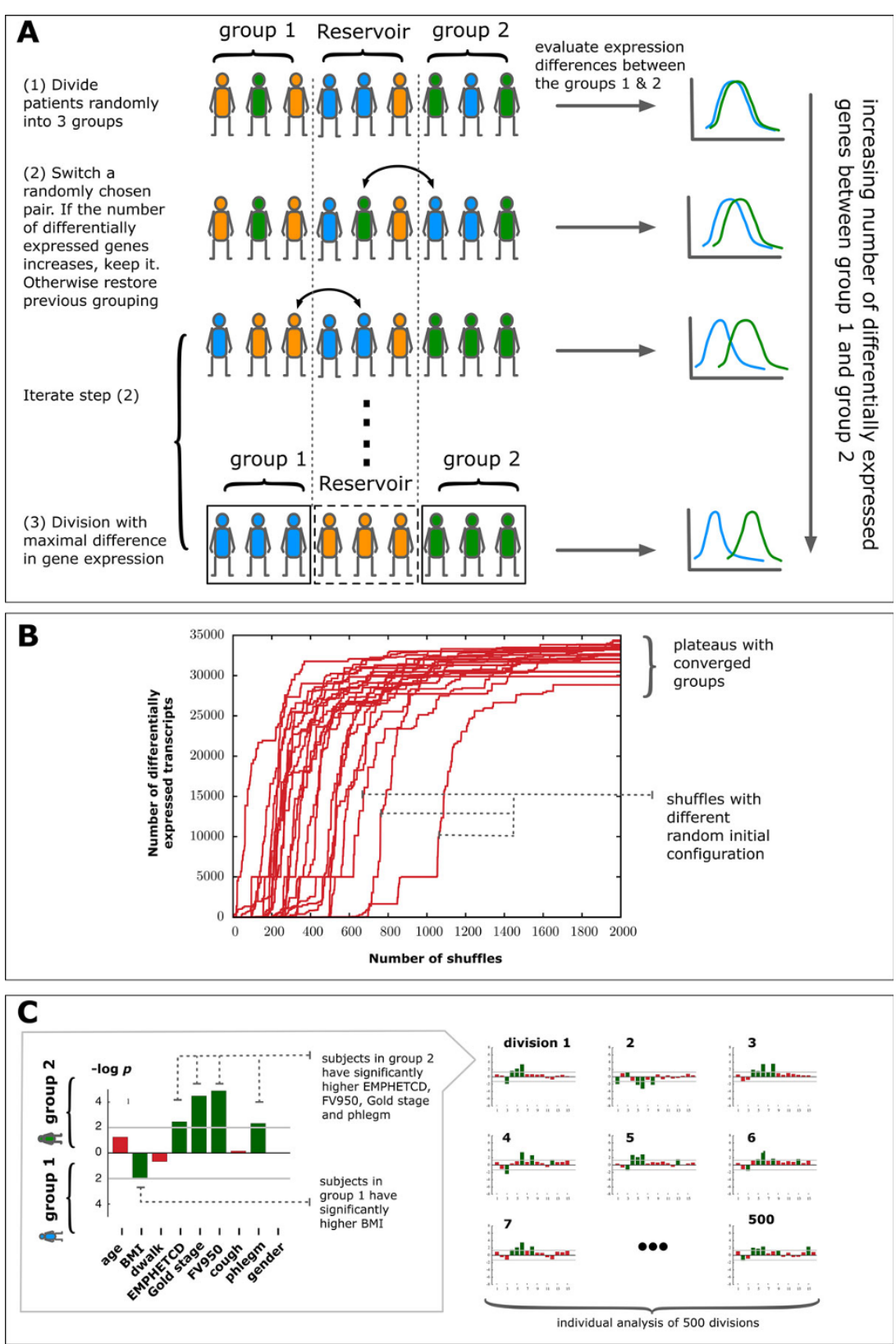

Figure 1 Schematic representation of the diVIsive Shuffling Approach (VIStA). A Initially the subjects are divided randomly into three groups; gene expression differences are calculated between group 1 \& 2, the third group serves as a reservoir for the subsequent shuffling steps. At each shuffling step, a subject from group 1 or 2 is randomly exchanged with a subject from the reservoir. If the number of differentially expressed genes increases thereby, the swap is accepted, otherwise rejected. B 20 exemplary time series of the number of differentially expressed genes between group 1 \& 2 as a function of the number of attempted shuffles. The different curves correspond to different random initial divisions. After approximately 1000 shuffles the groups converge and present a large, stationary number of differentially expressed genes. C For each of the obtained divisions (500 in total), clinical characteristics in group 1 \& 2 are compared. 
(iv) An individual from group 1 or 2 is randomly swapped with an individual from the reservoir group 3. We repeat the SAM analysis, counting again the new number of differentially expressed genes (Figure 1A). If this count increases, the swap is accepted, otherwise rejected.

(v) Step (ii) is iterated until the number of differentially expressed genes reaches a plateau (Figure 1B), typically after approximately 1000 attempted swaps. The corresponding groups $1 \& 2$ represent a combination of patients with high differential gene expression.

Starting with different random initial configurations, we repeat the whole procedure (i) through (iii) 500 times, resulting in 500 end configurations, each characterized by a large number of differentially expressed genes. In order to explore the extent to which these 500 subdivisions are clinically relevant and distinct, we analyze them individually for statistically significant differences in clinical characteristics between the members of group 1 and 2. For each subdivision, we identify the set of clinical characteristics (Table 2) that differ significantly between patients in group 1 and group 2 using a Mann-Whitney-U-test (significance threshold of $p$-value $\leq 0.05$ ) for all continuous characteristics (e.g. BMI) and Fisher's exact test for binary characteristics (e.g. gender) (Figure $1 \mathrm{C}$ ). We find that with the exception of two subdivisions, all the remaining 498 subdivisions show a statistically significantly difference in at least one clinical characteristic. This suggests that the shuffling algorithm indeed does identify biologically or clinically distinct divisions of patients in most cases. The frequency with which individual clinical characteristics appear as significantly different between the two groups can therefore be used to identify the combinations of clinical characteristics that co-determine gene expression differences.

Note that the VIStA approach is fundamentally different from clustering techniques like hierarchical or $k$-means clustering. The latter attempt to identify cohesive groups based on similarity, while VIStA, on the contrary, is a divisive algorithm based on maximizing the differences between groups. Another important difference to standard clustering approaches is that by design VIStA is able to identify a large number of locally optimal divisions.

\section{Technical considerations}

We use a relatively low confidence cut-off of FDR $\leq 0.1$ for the SAM analysis in steps $(i)$ and ( $i i)$ in order to facilitate the emergence of an initial "seed"-grouping. Sensitivity of parameter estimates were robust to variation in the exact choice. Within the SAM framework, the FDR is based on a comparison with random permutations, see [13] for details.

Note that instead of SAM one could also use other approaches to determine the number of differentially expressed genes at each iteration step, for example using the $p$-values of simple t-tests or a minimal foldchange. As VIStA consists of repeated differential expression analyses, the same limitations as for conventional approaches apply for the minimal number of subjects and general data quality.

We implemented a reservoir of 40 subjects (group 3) in order to resemble a gene expression analysis based on extremes, e.g. the $25 \%$ of subjects with the lowest BMI vs the $25 \%$ of subjects with the highest BMI. In principle, the third group is not strictly necessary, as shuffling can be performed between two groups. Increasing the size of the reservoir group could affect power through selection of more extreme subjects or by reducing the sample size for the differential expression analysis, so it will depend on the concrete application, whether or not a reservoir is useful.

As detailed below, we find that 500 independent runs of VIStA provided sufficient statistical power for a robust distinction between four different subgroups in this study. Generally, a higher number of independent runs could lead to the discovery of more subtle subgroups. It is important to note, however, that the predictive power of the approach is ultimately limited by the quality and size of the expression data, as well as the clinical characteristics.

The algorithm was implemented in the programming language C. A single run with 2,000 iterations takes around three hours on a standard PC. However, the vast majority of the computing time is used to perform the SAM analysis, so using a simpler technique for the differential gene expression analysis would drastically speed up the execution time if necessary.

\section{Results \& discussion \\ Differential gene expression of single clinical characteristics}

We first attempted to identify statistically significant gene expression differences between patient groups that differ in a single clinical characteristic. To be specific, we aimed to identify genes that were differentially expressed at FDR $<0.05$ using bins of clinical characteristics as presented in Table 2, such as COPD severity, the history of exacerbation or BMI. As shown in Table 2, apart from the severity of airflow limitation as assessed by the GOLD stage, none of the other clinical measures identified significant gene expression changes. This failure suggests that these clinical characteristics are not sufficiently discriminative to capture gene expression variation in COPD. We hypothesized that there are indeed potential molecular drivers to disease heterogeneity, but a single clinical characteristic is unable to capture them. Therefore, we developed an inverse (divisive) clustering methodology to group the 140 COPD patients included in the 
study based on their gene expression patterns, and then explored the clinical characteristics of the obtained groups (Figure 1).

Figure 2 presents the results of the VIStA analysis, offering a comparison of the clinical characteristics (GOLDCD, FV950, EMPHETCD, BMI, PHLEGM, AGE, DWALK, COUGH and Sex) and inflammatory biomarker levels (interleukin (IL)-6, IL-8, high-sensitivity C-reactive protein (HSCRP), chemokine motif (C-C) ligand 18 (CCL18), surfactant protein D (SPD), fibrinogen (FIBRINOG), and tumor necrosis factor alpha (TNFA) associated with patient subtypes that display the most extreme sputum gene expression pattern differences. We found that the severity of airflow limitation (GOLDCD) was the single most important determinant of differential gene expression, being statistically significant in $95 \%$ of all VIStA outputs $(n=477$, Figure 2A). This is consistent with our finding discussed above that

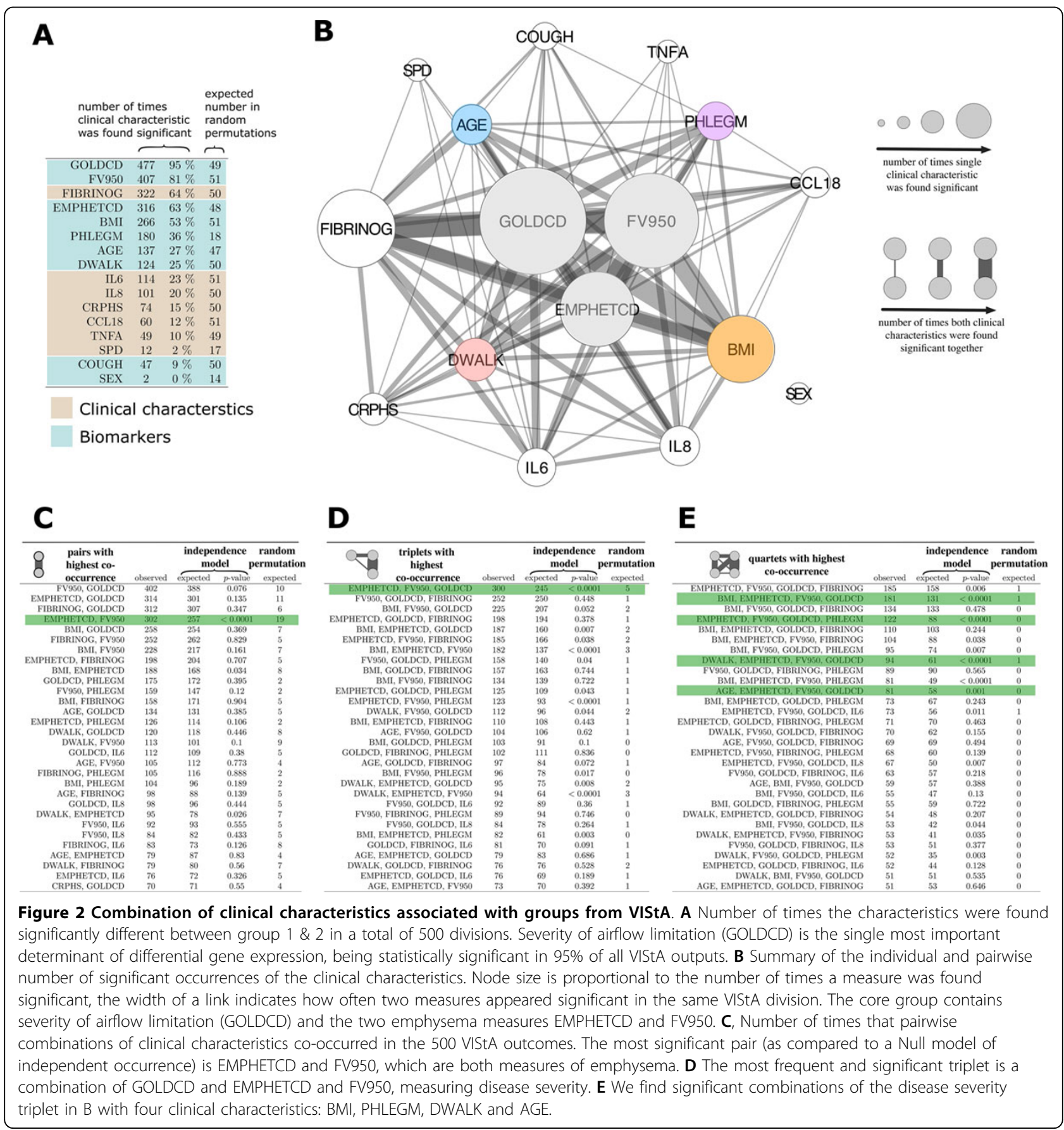


GOLDCD was the only single clinical variable associated with differential gene expression. The second most common clinical determinant of differential sputum gene expression was emphysema, quantified by either density mask analysis (FV950) or assessed qualitatively by the radiologist (EMPHETCD) (81\% and $63 \%$ of all VIStA outcomes, respectively, Figure 2A) whereas BMI, Phlegm, age and DWALK were observed in 53\%, 36\%, 27\% and $25 \%$ of the VIStA outcomes, respectively (Figure $2 \mathrm{~A}$ ). Plasma fibrinogen was the most frequently identified systemic biomarker (64\% of all VIStA outcomes),

\section{Combination of clinical traits from VIStA}

Figure 2B illustrates how often combinations (pairs) of significant single clinical characteristics (or inflammatory biomarkers) co-occur in the different VIStA subtypes by the width of the links between them. The statistical significance of each co-occurrence (Figure 2C-E) was calculated using a binomial model that assumes independence of the individual characteristics or biomarker levels as the Null hypothesis. In order to quantify the extent to which the VIStA outcomes could reflect spurious associations, we also generated 10,000 random divisions of the patients and analyzed how often the individual characteristics and their combinations appear as significant (Figure 2C-E). We find that the divisions obtained by VIStA show a much higher number of significant clinical characteristics than expected by chance, with the exceptions of the biomarkers CCL18, TNFA and SPD and the variables COUGH and SEX. Similarly, also combinations of significant characteristics appear more frequent than for randomly assigned division. We observed (Figure 2C) that the pairwise co-occurrences of clinical characteristics and inflammatory biomarkers were dominated by airflow limitation severity (GOLDCD). Other characteristics frequently observed in combinations include emphysema (EMPHETCD or FV950), fibrinogen levels, phlegm, BMI and age. Most pairs appear with the frequency expected for the Null hypothesis of independent individual clinical characteristics (see the many non-significant $p$-values in Figure 2C-E), implying that their association is not significant (e.g. EMPHETCD and GOLDCD). A notable exception is EMPHETCD and FV950, whose statistical association is expected, given that the two variables are not independent but are different measures of the same clinical characteristic (emphysema). Figure 2D, E shows the observed and expected co-occurrence of triplets and quartets of clinical characteristics and inflammatory biomarkers. The most frequent and significant triplet consists of severity of airflow limitation (GOLDCD) and the two emphysema measures EMPHETCD and FV950. GOLDCD and either one of the severity of emphysema measures FV950 or EMPHETCD co-occurred in almost all triplets, which is again expected given their pathobiological relationship in patients with COPD. Figure $2 \mathrm{E}$ lists the most frequent combinations of four variables. We find that the most significant combinations are those which include the triple GOLDCD, FV950 and EMPHETCD, together with one additional variable, the most significant being FIBRINOGEN, BMI, PHLEGM, DWALK and age. In the following, however, we have not considered fibrinogen as the basis for a subtype since it is a biomarker rather than a clinical characteristic.

In summary, Figure $2 \mathrm{C}-\mathrm{E}$ suggests four distinct clinical parameters that define groups of patients with considerable gene expression differences. In all groups the patients are characterized by different disease severity (GOLDCD) and emphysema (i.e. EMPHETCD and FV950) but in addition, each group also has one clear distinctive parameter: high/ low BMI (Group I), exercise capacity (DWALK) (Group II), Age (Group III) or presence/absence of phlegm production (Group IV) (Table 3). For example, group IA has high GOLDCD, emphysema, FV950 and low BMI, while group IB has low GOLDCD, emphysema, FV950 and high BMI.

To further characterize these subtypes suggested by VIStA we subdivided the full set of all 140 ECLIPSE patients according to the identified clinical characteristics, resulting in 8 groups of 15 to 28 patients. First, we explored a number of clinical, biomarker and cell count measures of the subjects in each group. We find, for example, that serum levels of the biomarkers IL6, IL8 and SPD are significantly higher in group IIIB than in IIIA, a difference that was not observed in other groups. Similarly, the proportion of neutrophils and lymphocytes in sputum were significantly higher in group IIIB in comparison to IIIA (Table 3).

We then performed a separate differential gene expression analysis (now with a more stringent FDR $<0.05$ ) on the subgroups, finding 821 unique genes for Group I, 528 for Group II, 1,394 genes for Group III and 637 for Group IV (Figure 3B). The four groups share 7,592 genes that are differentially expressed in all of them. As expected, $80 \%$ of these genes were previously identified as differentially expressed comparing patients with moderate (GOLD 2) with those with more severe disease (GOLD 3\&4) (Figure 3C). We conclude that the common core is dominated by severity of COPD, while the uniquely differentially expressed genes between the groups represent additional variation.

\section{Specific genes \& pathways in the groups from VIStA}

For a further evaluation of the molecular level differences among the four groups, we performed a pathway enrichment analysis for the core set of genes common to all groups, as well as for the unique gene set of each group. Pathway annotations were obtained from the Molecular Signatures Database (MSigDB) published by the Broad Institute, Version 3.1 [14]. MSigDB integrates several 
Table 3 Summary of the clinical measures, biomarkers, and cell counts among the four groups of COPD patients identified from the results of Figure 2: each group combines GOLDCD, EMPHETCD and FV950, with either BMI (Group I), DWALK (Group II), AGE (Group III) or Phlegm (Group IV).

\begin{tabular}{|c|c|c|c|c|c|c|c|c|c|c|c|c|}
\hline & $\begin{array}{l}\text { Group-IA } \\
(n=25)\end{array}$ & Group-IB, $(n=23)$ & $p$-values & $\begin{array}{c}\text { Group-IIA } \\
(n=21)\end{array}$ & $\begin{array}{c}\text { Group-IIB } \\
(\mathrm{n}=32)\end{array}$ & $p$-values & Group -IIIA $(n=15)$ & $\begin{array}{c}\text { Group-IIIB } \\
(n=28)\end{array}$ & $p$-values & $\begin{array}{c}\text { Group-IVA } \\
(\mathrm{n}=20)\end{array}$ & $\begin{array}{c}\text { Group-IVB } \\
(\mathrm{n}=26)\end{array}$ & $p$-values \\
\hline Age & 65.4 & 65.4 & - & 63.9 & 65.4 & - & 58.73 & 68.7 & $* * *$ & 63 & 65.96 & - \\
\hline Lung Function & & & - & & & - & & & - & & & - \\
\hline FEV1 & 1.72 & 0.89 & $* * *$ & 1.7 & 0.9 & $* * *$ & 1.72 & 0.93 & $* *$ & 1.79 & 0.9 & $* * *$ \\
\hline FEV1/FVC (\%) & 57.88 & 32.43 & $* * *$ & 55.0 & 32.5 & $* * *$ & 56.53 & 33.93 & $* * *$ & 57.1 & 33.04 & $* * *$ \\
\hline FEV1 reversibility (\%) & 7.64 & 4.73 & $* * *$ & 11.5 & 7.2 & $* * *$ & 11.62 & 5.93 & $* * *$ & 10.4 & 5.5 & *** \\
\hline Radiologist Emphysema & & & - & & & - & & & - & & & - \\
\hline Emphysema severity & 1.2 & 4.2 & $* * *$ & 1.3 & 4.2 & $* * *$ & 1.336 & 3.7 & $* * *$ & 1.275 & 4.2 & $* * *$ \\
\hline Densitometric Emphysema & & & - & & & - & & & - & & & - \\
\hline Emphysema at $-950 \mathrm{HU}$ & 6.98 & 33.42 & $* * *$ & 6.6 & 31.7 & $* * *$ & 7.71 & 28.09 & $* * *$ & 7.06 & 33.42 & *** \\
\hline Airflow Obstruction & & & - & & & - & & & - & & & - \\
\hline GOLD Stage & 2 & 3.3 & $* * *$ & 2.0 & 3.3 & $* * *$ & 2 & 3.2 & $* * *$ & 2 & 3.3 & $* * *$ \\
\hline Body Mass Index & 30.76 & 21.21 & $* * *$ & 27.3 & 24.2 & * & 29.87 & 25.8 & - & 28.67 & 24.42 & * \\
\hline $\begin{array}{c}\text { Chronic Bronchitis (ATS_CB) } \\
1=\text { no-CB } \\
\text { Phelgm }\end{array}$ & $1=24 \%$ & $1=30.4 \%$ & - & $1=85.7 \%$ & $1=62.5 \%$ & - & $1=6.7 \%$ & $1=37 \%$ & - & $1-100 \%$ & $1=46.2 \%$ & *** \\
\hline $1=$ no chronic phlegm & $1=56 \%$ & $1=35 \%$ & - & $1=62 \%$ & $1=41 \%$ & - & $1=66.6 \%$ & $1=33 \%$ & - & $1-100 \%$ & $1=0 \%$ & $* * *$ \\
\hline 6 Minute Walk Distance & 428.32 & 330.02 & $* *$ & 508.8 & 273.9 & $* * *$ & 438.97 & 321.83 & $* *$ & 462.59 & 322.9 & $* *$ \\
\hline Exacerbations $0=$ no-Exacerbations & $0=68 \%$ & $0=34.8 \%$ & - & $0=71.4 \%$ & $0=28.1 \%$ & $* *$ & $0=60 \%$ & $0=37 \%$ & - & $0=70 \%$ & $0=38.5 \%$ & * \\
\hline CCL6 & 7.3 & 6.33 & - & 7.0 & 6.8 & - & 6.19 & 6.73 & - & 8.64 & 6.9 & - \\
\hline IL6 & 5.65 & 20.2 & - & 4.3 & 18.6 & - & 2.79 & 6.89 & ** & 3.72 & 18.53 & - \\
\hline IL8 & 8.88 & 10.77 & - & 8.3 & 9.4 & - & 7.5 & 10.28 & * & 9.8 & 10.65 & - \\
\hline TNFa & 26.99 & 160.32 & - & 31.7 & 162.9 & - & 2.35 & 60.44 & - & 24.14 & 142.3 & - \\
\hline CCL18 & 130.3 & 117.59 & - & 126.9 & 124.4 & - & 115.8 & 117.94 & - & 134 & 126.19 & - \\
\hline CRPHS & 10.4 & 9.6 & - & 9.9 & 9.5 & - & 5.7 & 9.72 & - & 510 & 8.5 & - \\
\hline FIBRINOG & 494.9 & 499.1 & - & 481.0 & 506.2 & - & 456.8 & 498.58 & - & 510.8 & 489.84 & - \\
\hline SPD & 129.64 & 110.94 & - & 124.9 & 119.1 & - & 79.73 & 116.3 & * & 138.76 & 109.7 & - \\
\hline mMRC & 3 & 2.09 & $* *$ & 1.0 & 2.4 & $* * *$ & 1.21 & 2.04 & * & 1.1 & 2.04 & * \\
\hline SGRQ & 43.29 & 55.55 & $* *$ & 35.9 & 56.0 & $* * *$ & 41.8 & 52.87 & * & 36 & 57.73 & $* * *$ \\
\hline FFMI & 19.53 & 16.13 & $* * *$ & 18.5 & 17.1 & * & 18.48 & 17.8 & - & 18.83 & 17.15 & * \\
\hline$\%$ Fat (Tissue) & 34.92 & 29.08 & $* *$ & 31.0 & 31.7 & - & 35.96 & 31.94 & - & 32.69 & 31.25 & - \\
\hline & & & - & & & - & & & - & & & - \\
\hline Neutrophils, \% Neut_Blq & 61.38 & 64.87 & - & 60.7 & 67.0 & $* *$ & 61.34 & 66.69 & * & 62.08 & 65.55 & - \\
\hline Eosinophils, \% Eos blq & 3 & 3.1 & - & 3.5 & 3.1 & - & 2.48 & 2.92 & - & 3.26 & 3.3 & - \\
\hline Lymphocytes, \% lymhblq & 28.63 & 24.84 & - & 28.6 & 23.2 & * & 29.19 & 23.55 & * & 27.77 & 23.688 & - \\
\hline
\end{tabular}

${ }^{*}=p$-value $<0.05 ; * *=p$-value $<0.01 ; * * *=p$-value $<0.0001 ;-=$ not significant 


\section{A Four subtypes identified by VIStA}

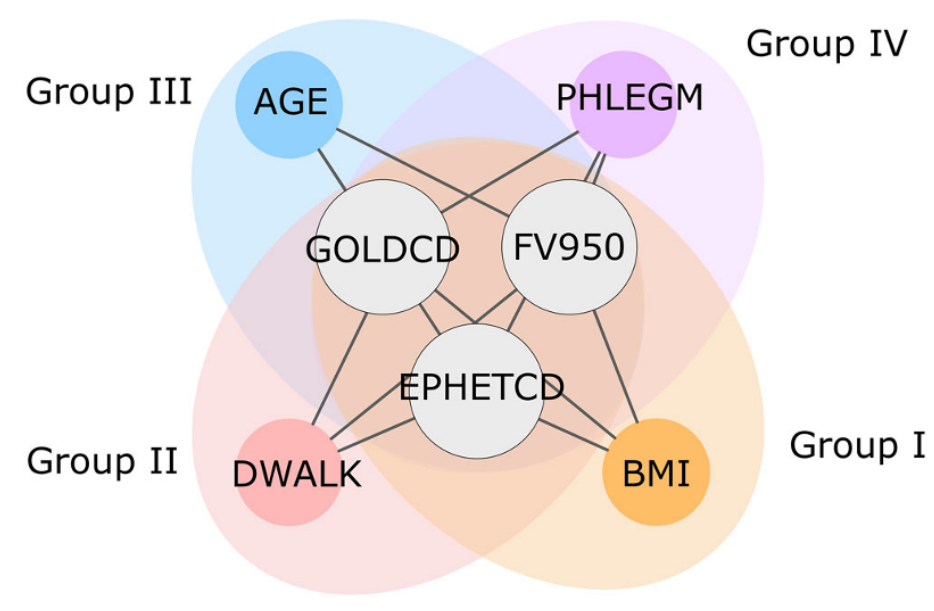

B

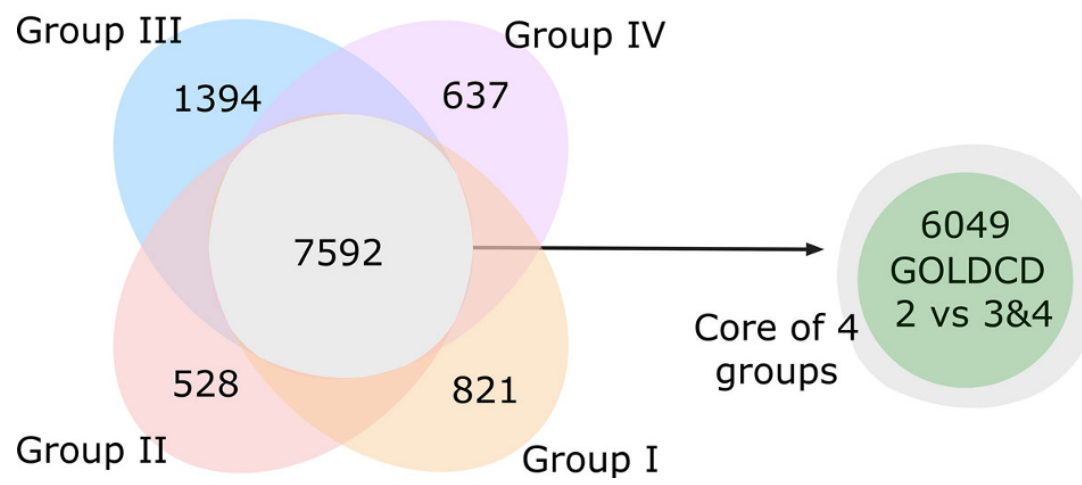

Figure 3 Four subtypes and differentially expressed genes. A The combinations of phenotypic measures that define the subtypes predicted by the VIStA method: all four subtypes share a common core of high values of GOLDCD, FV950 and EMPHETCD, reflecting disease severity. Each of the individual subtypes I-IV presents one additional clinical characteristic: BMI (subtype I), DWALK (II), AGE (III) or PHLEGM (IV). B Venn diagram showing the number of differentially expressed genes unique to each subtype, as well as common to all four subtypes. The common genes show a large overlap with the genes differentially expressed between subjects with GOLDCD 2 and subjects with GOLDCD 3\&4, indicating that these genes reflect mostly disease severity.

different pathway databases, we use KEGG, Biocarta and Reactome. The enrichment analysis between a given gene set and a pathway was done using Fisher's exact test. As shown in Table 4, the top pathways show little overlap between the four groups, providing further evidence for VIStA's ability to capture molecular elements that are specific to each subtype. Several identified pathways were related to metabolism, diabetes and inflammation. Group 1 was most enriched with inflammatory pathways including for example the FC-Gamma-R mediated phagocytosis $(p=0.007)$ and CDC6-association with ORC:origin-complex pathways $(p=0.15)$. Further pathways include small lung cancer $(p=0.004)$ and maturity onset diabetes of the young $(p=0.009)$ [15]. Group II was enriched with lipid transport and beta-cell and insulin signaling pathways like beta cell $(p=0.005)$, HDL mediated lipid transport $(p=0.006)$ and GTP hydrolysis pathways $(p=$ 0.007). In group III, pathways related to cell cycle control like mitotic prometaphase $(p=0.0048)$, and downstream signaling pathways $(p=0.003)$ with innate-immunity and GAB1 signaling were enriched. In group IV, distinct gap channel and inflammation pathways were identified like peptide ligand binding $(p=0.0006)$, gap-junction assembly $(p=0.0008)$ and chemokine signaling pathways $(p=$ 0.0013).

Finally, we identified genes with at least a 2 -fold change (FC) in expression $[16,17]$ at an FDR of $<0.05$, see Table 5 for the specific set of upregulated and 
Table 4 The 10 most strongly enriched pathways in the set of genes common among all four groups described in table 3, as well as in the individual gene sets of each group.

\begin{tabular}{|c|c|c|c|}
\hline \multicolumn{4}{|l|}{ Top ten pathways among Common Genes } \\
\hline pathway & p-value & overlap & all pathway genes \\
\hline REACTOME_GENE_EXPRESSION & $1.22 E-35$ & 235 & 425 \\
\hline REACTO ME_DIABETES_PATHWAYS & $1.91 \mathrm{E}-33$ & 214 & 383 \\
\hline REACTOME_METABOLISM_OF_PROTEINS & $9.48 \mathrm{E}-28$ & 134 & 215 \\
\hline REACTOME_CELL_CYCLE_MITOTIC & $7.34 \mathrm{E}-25$ & 167 & 306 \\
\hline $\begin{array}{l}\text { REACTOME_GLUCOSE_REGULATION_OF_ } \\
\text { INSULIN_SECRETION }\end{array}$ & $1.24 \mathrm{E}-23$ & 104 & 161 \\
\hline KEGG_HUNTINGTONS_DISEASE & $3.16 \mathrm{E}-23$ & 114 & 185 \\
\hline REACTOME_INTEGRATION_OF_ENERGY_METABOLISM & $1.09 \mathrm{E}-21$ & 130 & 229 \\
\hline REACTOME_ELECTRON_TRANSPORT_CHAIN & $1.11 \mathrm{E}-21$ & 60 & 75 \\
\hline REACTOME_RNA_POLYMERASE_I_III_AND_MITOCHONDRIAL_TRANSCR.PT.ON & $2.72 \mathrm{E}-21$ & 82 & 120 \\
\hline REACTOME_INFLUENZA_LIFE_CYCLE & $1.11 \mathrm{E}-20$ & 89 & 137 \\
\hline \multicolumn{4}{|l|}{ Top ten pathways among Group 1 Genes } \\
\hline pathway & $p$-value & overlap & all pathway genes \\
\hline REACTOME_INORGANIC_CATION_ANION_SLC_TRANSPORTERS & 0.00133586 & 7 & 94 \\
\hline KEGG_SMALL_CELL_LUNG_CANCER & 0.00359651 & 6 & 84 \\
\hline KEGG_FC_GAMMA_R_MEDIATED_PHAGOCYTOSIS & 0.00723812 & 6 & 97 \\
\hline KEGG_MATURITY_ONSET_DIABETES_OF_THE_YOUNG & 0.00921957 & 3 & 25 \\
\hline REACTOME_AM.NO_ACID_AND_OLIGOPEPTIDE_SLC_TRANSPORTERS & 0.00984371 & 4 & 48 \\
\hline REACTOME_SLC_MEDIATED_TRANSMEMBRANE_TRANSPORT & 0.01009928 & 8 & 169 \\
\hline KEGG_B_CELL_RECEPTOR_SIGNALING_PATHWAY & 0.01020969 & 5 & 75 \\
\hline KEGG_GLYCOSPHINGOLIPID_BIOSYNTHESIS_LACTO_AND_NEOLACTO_SERIES & 0.0102887 & 3 & 26 \\
\hline REACTOME_NUCLEAR_RECEPTOR_TRANSCRIPTION_PATHWAY & 0.01133769 & 4 & 50 \\
\hline REACTOME_CDC6_ASSOCIATION_WITH_THE_ORC:ORIGIN_COMPLEX & 0.01516009 & 2 & 11 \\
\hline \multicolumn{4}{|l|}{ Top ten pathways among Group II Genes } \\
\hline pathway & $p$-value & overlap & all pathway genes \\
\hline REACTOME_REG ULATION_OF_GENE_EXPRESSIO N_IN_B ETA_CELLS & 0.00552 & 5 & 101 \\
\hline REACTOME_HDL_MEDIATED_LIPID_TRANSPORT & 0.00637 & 2 & 11 \\
\hline REACTOME_GTP_HYDROLYSIS_AND_JOINING_OF_THE_60S_RIBOSOMAL_SUBUNIT & 0.00675 & 5 & 106 \\
\hline REACTOME_FACILITATIVE_NA_INDEPENDENT_GLUCOSE_TRANSPORTERS & 0.00759 & 2 & 12 \\
\hline REACTOME_REGULATION_OF_BETA_CELLDEVELOPMENT & 0.00911 & 5 & 114 \\
\hline REACTOME_TRANSLATION & 0.01121 & 5 & 120 \\
\hline REACTOME_TRANSMEMBRANE_TRANSPORT_OF_SMALL_MOLECULES & 0.01148 & 7 & 218 \\
\hline REACTOME_IRS_RELATED_EVENTS & 0.01182 & 4 & 79 \\
\hline REACTOME_INFLUENZA_LIFE_CYCLE & 0.01889 & 5 & 137 \\
\hline REACTOME_DEADENYLATION_OF_MRNA & 0.02469 & 2 & 22 \\
\hline \multicolumn{4}{|l|}{ Top ten pathways among Group III Genes } \\
\hline pathway & $p$-value & overlap & all pathway genes \\
\hline REACTOME_DOWN_STREAM_SIGNAL_TRANSDUCTION & 0.00302075 & 5 & 35 \\
\hline REACTOME_GAB1_SIGNALOSOME & 0.00324484 & 3 & 11 \\
\hline REACTOME_SIGNALING_IN_IMMUNE_SYSTEM & 0.00470548 & 20 & 366 \\
\hline REACTOME_MITOTIC_PROMETAPHASE & 0.00489389 & 8 & 92 \\
\hline REACTOME_INNATE_IMMUNITY_SIGNALING & 0.00584887 & 10 & 136 \\
\hline REACTOME_SIGNALLING_TO_RAS & 0.0060289 & 4 & 26 \\
\hline $\begin{array}{l}\text { REACTOME_FORMATION_OF_PLATELET_ } \\
\text { PLUG }\end{array}$ & 0.00753191 & 12 & 186 \\
\hline REACTOME_GRB2_SOS_PROVIDES_LINKAGE_TO_MAPK_SIGNALING_FOR_INTERGRINS & 0.00821656 & 3 & 15 \\
\hline REACTOME_MYOGENESSIS & 0.00895252 & 4 & 29 \\
\hline REACTOME_HEMOSTASIS & 0.01301061 & 15 & 274 \\
\hline
\end{tabular}


Table 4 The 10 most strongly enriched pathways in the set of genes common among all four groups described in table 3, as well as in the individual gene sets of each group. (Continued)

\begin{tabular}{llcc}
\hline Top ten pathways among Group IV Genes & & \\
\hline pathway & $\boldsymbol{p}$-value & overlap & all pathway genes \\
REACTOME_PEPTIDE_LIGAND_BINDING_RECEPTORS & 0.00059 & 12 & 173 \\
REACTOME_GAP_JUNCTION_ASSEMBLY & 0.00076 & 4 & 19 \\
KEGG_CHEMOKINE_SIGNALING_PATHWAY & 0.00133 & 12 & 190 \\
REACTOME_GAP_JUNCTION_TRAFICKING & 0.00340 & 4 & 28 \\
REACTOME_CHEMOKINE_RECEPTORS_BIND_CHEMOKINES & 0.00787 & 5 & 55 \\
REACTOME_ACTIVATION_OF_ATR_IN_RESPONSE_TO_REPLICATION_STRESS & 0.00936 & 4 & 37 \\
REACTOME_SIGNALING_IN_IMMUNE_SYSTEM & 0.00943 & 16 & 766 \\
KEGG_T_CELL_RECEPTOR_SIGNALING_PATHWAY & 0.01126 & 7 & 108 \\
REACTOME_CELL_CYCLE_CHECKPOINTS & 0.01237 & 7 & 110 \\
KEGG_NATURAL_KILLER_CELL_MEDIATED_CYTOTOXICITY & 0.01263 & 8 & 137 \\
\hline
\end{tabular}

downregulated genes in each subgroup. For example, $M M P 7$ was found to be upregulated in group I (BMI), consistant with findings in [18], where nutritionally induced obese mice showed alterations in $M M P s$ and TIMPs expression, thus providing further evidence for the role of these proteolytic system genes in COPD subtype with low BMI.

\section{Conclusion}

We have found that with the exception of severity of airflow limitation, categorizing COPD subtypes according to a single clinical characteristic does not yield groups of patients with significant gene expression differences. In this study, we therefore introduced a novel methodology that allowed us to identify combinations of clinical characteristics that correspond to clear gene expression differences.

Our results suggest that while gene expression differences are mainly driven by the severity of airflow limitation and the extent of emphysema, a smaller, yet discriminative contribution is also observed for a set of additional clinical characteristics: BMI, distance walked, age and chronic phlegm production, each defining a subtype of patients. Validation of these groups and the underlying pathways

Table 5 Top ten upregulated and downregulated unique genes and their fold-change (FC) in each group (In group II, only five unique genes are downregulated).

\begin{tabular}{|c|c|c|c|c|c|c|c|}
\hline \multicolumn{2}{|c|}{ Group 1} & \multicolumn{2}{|c|}{ Group II } & \multicolumn{2}{|c|}{ Group III } & \multicolumn{2}{|c|}{ Group IV } \\
\hline Gene & $\mathrm{FC}$ & Gene & $\mathrm{FC}$ & Gene & $\mathrm{FC}$ & Gene & $\mathrm{FC}$ \\
\hline LOC100127940 & 2.8 & RP-3377H14.5 & 2.4 & DDX3Y & 4.6 & IL1F9 & 2.5 \\
\hline PDCD6 & 2.4 & ZFYVE16 & 2.2 & EIF1AY & 3.2 & IL23A & 2.5 \\
\hline AHRR & 2.4 & TGFBR1 & 2.2 & HELB & 3 & TUB & 2.4 \\
\hline CD1B & 2.4 & MARCH6 & 2.2 & LOC100130224 & 2.9 & GJB2 & 2.3 \\
\hline $\mathrm{KIT}$ & 2.4 & CAPZA1 & 2.2 & UTY & 2.9 & CD22 & 2.3 \\
\hline CADM1 & 2.3 & KIAA0319 & 2.2 & ADORA3 & 2.9 & FAF1 & 2.3 \\
\hline MMP7 & 2.3 & $\mathrm{DHX36}$ & 2.2 & ARNT2 & 2.9 & MB0AT7 & 2.3 \\
\hline C20orf197 & 2.3 & DLGAP4 & 2.1 & CXCL14 & 2.6 & SULT2A1 & 2.3 \\
\hline RNF144A & 2.2 & RIF1 & 2.1 & TMEM61 & 2.6 & TMEM88 & 2.3 \\
\hline MYO1B & 2.2 & NT5C2 & 2.1 & PPARGC1B & 2.6 & CHST7 & 2.3 \\
\hline SGK493 & -2.0 & TIFAB & -2.0 & C1orf201 & -2.5 & VASH1 & -2.3 \\
\hline ALS2CR4 & -2.1 & CCDC42 & -2.2 & ST3GAL3 & -2.5 & LINC00607 & -2.3 \\
\hline ENPP5 & -2.2 & HBE1 & -2.2 & APOOL & -2.6 & KLHDC7B & -2.3 \\
\hline FLJ14082 & -2.2 & NAPSB & -2.2 & IL28RA & -2.6 & $\mathrm{DHODH}$ & -2.3 \\
\hline LOC1441204 & -2.2 & C4orf7 & -3.8 & ZNF624 & -2.6 & CDDC113 & -2.3 \\
\hline LOC100134569 & -2.2 & & & SMAD5 & -2.6 & IGF2BP3 & -2.3 \\
\hline FAM101A & -2.7 & & & NRP1 & -2.6 & C3orf27 & -2.3 \\
\hline LOC92270 & -2.8 & & & LOC654342 & -2.6 & ZNF618 & -2.3 \\
\hline HPR & -2.9 & & & TSIX & -3.3 & AKR1C4 & -2.4 \\
\hline $\mathrm{HP}$ & -2.9 & & & XIST & -4.1 & LOC401321 & -2.4 \\
\hline
\end{tabular}


will require replication in a second cohort of COPD subjects. Note that additional differences may also exist for clinical characteristics that have not been considered in the present study.

The observed subgroups with combinations of different clinical characteristics are consistent with the clinical heterogeneity of COPD, where a given patient may manifest more than one measurable feature of COPD, suggesting either that the underlying mechanisms contribute to more than one feature or that multiple mechanisms are maladapted in an individual.

While we focused on COPD in this study, the proposed VIStA method can be more generally applied to any other complex, heterogeneous disease and presents a promising approach to the important problem of disease heterogeneity and subtyping/subgrouping. A better understanding of this problem is invaluable, for example, for improving the selection of patients for evaluating novel agents. To the extent that gene expression reflects genetic and epigenetic variation, the subtypes identified by our method may further suggest different approaches to identifying genetic susceptibility.

\section{Competing interests}

RJM, RTS, BEM, NL. JR, CL, GB are employees of GlaxoSmithKline and own shares and share options in the company.

\section{Authors' contributions}

$J M, A S, A L B$ carried out the analysis and wrote the manuscript; $A A, B C, S R$, ES, RTS, BM, JR, NL provided expertise on the ECLIPSE data and COPD and wrote the manuscript; $\mathrm{MHC}, \mathrm{RM}, \mathrm{SG}, \mathrm{CL}, \mathrm{GB}$ advised on the analysis and wrote the manuscript.

\section{Acknowledgements}

This work was partially supported by MapGen grant (1U01HL108630-01), by the EC-FP7 Program, Synergy-COPD, GA n² 270086, as well as by by COSTBMBS, Action BM1006 "Next Generation Sequencing Data Analysis Network", SeqAhead.

Principal investigators and centers participating in ECLIPSE (NCT00292552): Bulgaria: Yavor Ivanov, Pleven; Kosta Kostov, Sofia. Canada: Jean Bourbeau, Montreal, Que; Mark Fitzgerald, Vancouver, BC; Paul Hernandez, Halifax, NS; Kieran Killian, Hamilton, On; Robert Levy, Vancouver, BC; Francois Maltais, Montreal, Que; Denis O'Donnell, Kingston, On. Czech Republic: Jan Krepelka, Praha. Denmark: JØrgen Vestbo, Hvidovre. Netherlands: Emiel Wouters, Horn. New Zealand: Dean Quinn, Wellington. Norway: Per Bakke, Bergen. Slovenia: Mitja Kosnik, Golnik. Spain: Alvar Agusti, Jaume Sauleda, Palma de Mallorca. Ukraine: Yuri Feschenko, Kiev; Vladamir Gavrisyuk, Kiev; Lyudmila Yashina, Kiev; Nadezhda Monogarova, Donetsk. United Kingdom: Peter Calverley, Liverpool; David Lomas, Cambridge; William MacNee, Edinburgh; David Singh, Manchester; Jadwiga Wedzicha, London. United States of America: Antonio Anzueto, San Antonio, TX; Sidney Braman, Providence, Rl; Richard Casaburi, Torrance CA; Bart Celli, Boston, MA; Glenn Giessel, Richmond, VA; Mark Gotfried, Phoenix, AZ; Gary Greenwald, Rancho Mirage, CA; Nicola Hanania, Houston, TX; Don Mahler, Lebanon, NH; Barry Make, Denver, CO; Stephen Rennard, Omaha, NE; Carolyn Rochester, New Haven, CT; Paul Scanlon, Rochester, MN; Dan Schuller, Omaha, NE; Frank Sciurba, Pittsburgh, PA; Amir Sharafkhaneh, Houston, TX; Thomas Siler, St. Charles, MO, Edwin Silverman, Boston, MA; Adam Wanner, Miami, FL; Robert Wise, Baltimore, MD; Richard ZuWallack, Hartford, CT. Steering Committee: Harvey Coxson (Canada), Lisa Edwards (GlaxoSmithKline, USA), David Lomas (UK), William MacNee (UK), Edwin Silverman (USA), Ruth Tal-Singer (Co-chair, GlaxoSmithKline, USA), Jørgen Vestbo (Co-chair, Denmark), Julie Yates (GlaxoSmithKline, USA). Scientific Committee: Alvar Agusti (Spain), Peter
Calverley (UK), Bartolome Celli (USA), Courtney Crim (GlaxoSmithKline, USA), Gerry Hagan (GlaxoSmithKline, UK), William MacNee (Chair, UK), Bruce Miller (GlaxoSmithKline, USA), Stephen Rennard (USA), Ruth Tal-Singer

(GlaxoSmithKline, USA), Emiel Wouters (The Netherlands), Julie Yates (GlaxoSmithKline, USA).

\section{Declarations}

The publication costs for this article were funded by Northeastern University, MA, USA.

This article has been published as part of BMC Systems Biology Volume 8 Supplement 2, 2014: Selected articles from the High-Throughput Omics and Data Integration Workshop. The full contents of the supplement are available online at http://www.biomedcentral.com/bmcsystbiol/supplements/ $8 / 52$.

\section{Authors' details}

${ }^{1}$ Center for Complex Networks Research and Department of Physics, Northeastern University, Boston, MA, 02115, USA. ${ }^{2}$ Center for Cancer Systems Biology, Dana-Farber Cancer Institute, Boston, MA, 02215, USA. ${ }^{3}$ Department of Theoretical Physics, Budapest University of Technology and Economics, Budapest, 1111 , Hungary. ${ }^{4}$ Channing Division of Network Medicine and Division of Pulmonary and Critical Care Medicine, Department of Medicine, Brigham and Women's Hospital, Harvard Medical School, Boston, MA, 02115, USA. ${ }^{5}$ GlaxoSmithKline, King of Prussia, PA, 19406, USA. ${ }^{6}$ University of Nebraska Medical Center, Omaha, NE, 68198, USA. ${ }^{7}$ Pulmonary and Critical Care Division, Brigham and Women's Hospital, Harvard Medical School, Boston, MA, 02115, USA. ${ }^{8}$ GlaxoSmithKline, Research Triangle Park, NC, 27709, USA. 'GlaxoSmithKline, Stevenage, Hertfordshire, SG1 2NY, UK. ${ }^{10}$ Hospital Clinic, IDIBAPS, Thorax Institute, University of Barcelona, 08036, Barcelona.

${ }^{11}$ Center for Network Science, Central European University, Budapest, 1051, Hungary. ${ }^{12}$ Department of Medicine, Brigham and Women's Hospital, Harvard Medical School, Boston, MA, 02115, USA. ${ }^{13}$ FISIB, CIBERES, Mallorca, 07110, Spain.

Published: 13 March 2014

\section{References}

1. Vestbo J, Hurd SS, Agusti AG, Jones PW, Vogelmeier C, Anzueto A, Barnes PJ, Fabbri LM, Martinez FJ, Nishimura M, Stockley RA, Sin DD, Rodriguez-Roisin R: Global strategy for the diagnosis, management, and prevention of chronic obstructive pulmonary disease: Gold executive summary. American journal of respiratory and critical care medicine 2013, 187(4):347-65.

2. Bhattacharya S, Srisuma S, Demeo DL, Shapiro SD, Bueno R, Silverman EK, Reilly JJ, Mariani TJ: Molecular biomarkers for quantitative and discrete copd phenotypes. American journal of respiratory cell and molecular biology 2009, 40(3):359-67.

3. Singh D, Fox SM, Tal-Singer R, Plumb J, Bates S, Broad P, Riley JH, Celli B: Induced sputum genes associated with spirometric and radiological disease severity in copd ex-smokers. Thorax 2011, 66(6):489-95.

4. Pierrou S, Broberg P, O'Donnell RA, Pawlowski K, Virtala R, Lindqvist E, Richter A, Wilson SJ, Angco G, Moller S, Bergstrand H, Koopmann W, Wieslander E, Stromstedt PE, Holgate ST, Davies DE, Lund J, Djukanovic R: Expression of genes involved in oxidative stress responses in airway epithelial cells of smokers with chronic obstructive pulmonary disease. American journal of respiratory and critical care medicine 2007, 175(6):577-86.

5. DeMeo D, Mariani T, Lange C, Lake S, Litonjua A, Celedon J, Reilly J, Chapman HA, Sparrow D, Spira A, Beane J, Pinto-Plata V, Speizer FE, Shapiro S, Weiss ST, Silverman EK: The serpine2 gene is associated with chronic obstructive pulmonary disease. Proceedings of the American Thoracic Society 2006, 3(6):502.

6. Spira A, Beane J, Pinto-Plata V, Kadar A, Liu G, Shah V, Celli B, Brody JS: Gene expression profiling of human lung tissue from smokers with severe emphysema. American journal of respiratory cell and molecular biology 2004, 31(6):601-10.

7. Agusti A, Calverley PM, Celli B, Coxson HO, Edwards LD, Lomas DA, MacNee W, Miller BE, Rennard S, Silverman EK, Tal-Singer R, Wouters E, Yates JC, Vestbo J: Characterisation of copd heterogeneity in the eclipse cohort. Respiratory research 2010, 11:122.

8. Agusti A, Sobradillo P, Celli B: Addressing the complexity of chronic obstructive pulmonary disease: from phenotypes and biomarkers to 
scale-free networks, systems biology, and p4 medicine. American journal of respiratory and critical care medicine 2011, 183(9):1129-37.

9. Vestbo J, Anderson W, Coxson HO, Crim C, Dawber F, Edwards L, Hagan G, Knobil K, Lomas DA, MacNee W, Silverman EK, Tal-Singer R: Evaluation of copd longitudinally to identify predictive surrogate end-points (eclipse). The European respiratory journal: official journal of the European Society for Clinical Respiratory Physiology 2008, 31(4):869-73.

10. Barabasi AL, Gulbahce N, Loscalzo J: Network medicine: a network-based approach to human disease. Nature reviews Genetics 2011, 12(1):56-68.

11. Coxson HO, Dirksen A, Edwards LD, Yates JC, Agusti A, Bakke P, Calverley PM, Celli B, Crim C, Duvoix A, Fauerbach PN, Lomas DA, MacNee W, Mayer RJ, Miller BE, Müller NL, Rennard SI, Silverman EK, TalSinger $R$, Wouters $E F$, Vestbo J: The presence and progression of emphysema in copd as determined by ct scanning and biomarker expression: a prospective analysis from the eclipse study. The Lancet Respiratory Medicine 2013, 1(2):129-136.

12. Agusti A, Edwards LD, Rennard SI, MacNee W, Tal-Singer R, Miller BE, Vestbo J, Lomas DA, Calverley PM, Wouters E, Crim C, Yates JC, Silverman EK, Coxson HO, Bakke P, Mayer RJ, Celli B: Persistent systemic inflammation is associated with poor clinical outcomes in COPD: a novel phenotype. PloS One 2012, 7(5):37483.

13. Larsson O, Wahlestedt C, Timmons JA: Considerations when using the significance analysis of microarrays (sam) algorithm. BMC bioinformatics 2005, 6:129.

14. Subramanian A, Tamayo P, Mootha VK, Mukherjee S, Ebert BL, Gillette MA, Paulovich A, Pomeroy SL, Golub TR, Lander ES, et al: Gene set enrichment analysis: a knowledge-based approach for interpreting genome-wide expression profiles. PNAS 2005, 102(43):15545-15550.

15. Luo J, Chen YJ, Narsavage GL, Ducatman A: Predictors of survival in patients with non-small cell lung cancer. Oncology nursing forum 2012, 39(6):609-16.

16. DeRisi J, Penland L, Brown PO, Bittner ML, Meltzer PS, Ray M, Chen Y, Su YA, Trent JM: Use of a cdna microarray to analyse gene expression patterns in human cancer. Nature genetics 1996, 14(4):457-60.

17. Wellmann A, Thieblemont C, Pittaluga S, Sakai A, Jaffe ES, Siebert $P$, Raffeld M: Detection of differentially expressed genes in lymphomas using cdna arrays: identification of clusterin as a new diagnostic marker for anaplastic large-cell lymphomas. Blood 2000, 96(2):398-404.

18. Maquoi E, Munaut C, Colige A, Collen D, Lijnen HR: Modulation of adipose tissue expression of murine matrix metalloproteinases and their tissue inhibitors with obesity. Diabetes 2002, 51(4):1093-101.

doi:10.1186/1752-0509-8-S2-S8

Cite this article as: Menche et al:: A diVlsive Shuffling Approach (VIStA)

for gene expression analysis to identify subtypes in Chronic Obstructive Pulmonary Disease. BMC Systems Biology 2014 8(Suppl 2):S8.

\section{Submit your next manuscript to BioMed Central and take full advantage of:}

- Convenient online submission

- Thorough peer review

- No space constraints or color figure charges

- Immediate publication on acceptance

- Inclusion in PubMed, CAS, Scopus and Google Scholar

- Research which is freely available for redistribution

Submit your manuscript at www.biomedcentral.com/submit
Biomed Central 